\title{
CALCULATION OF MAGNETIZATION OF PERMANENT MAGNETS AND OPTIMIZATION OF THE LOCATION OF INDUCTION MEASUREMENT POINTS USING THE METHOD OF INTEGRAL EQUATIONS WITH HYSTERESIS
}

DOI: 10.36724/2072-8735-2020-|4-6-39-47

\author{
Robert V. Harutyunyan, \\ Moscow State Technical University \\ named after NE Bauman, Moscow, Russia, \\ rob57@mail.ru
}

\begin{abstract}
The article proposes the development of the method for estimating the magnetization of permanent magnets by the known distribution of the magnetic field in the surrounding space, which differs from the known methods in that it allows to take into account the presence of soft magnetic ferromagnetic materials with known characteristics. The approach applied in the article to the problem of identification of the magnetic state of the system of permanent magnets and ferromagnets is based on the use of the corresponding integral equation of magnetostatics. The main objective of the study is to determine the conditions for the applicability of the modification of the previously developed numerical-experimental method for assessing the magnetization of permanent magnets for the diagnosis of electrical devices with permanent magnets in practice. For this purpose, the influence of neglect in the mathematical model of the magnetic field by the magnetic hysteresis of the frame material of the electrical device on the accuracy of the result of the inverse problem of identification of the magnetization of permanent magnets is investigated. We performed a series of numerical experiments, intended to establish the deviation of the calculated characteristics of the field in the magnetic material depending on the choice of the curves of magnetization within the area of the hysteresis loop of the material of the frame of the diagnosed electrical devices. In mathematical modeling, the presence of wind-ings with current was not taken into account. It is assumed that the magnetic system consists of permanent magnets and structural parts of ferromagnetic materials with known characteristics. For the regularization operator SLOUGH, used the method of A. N. Tikhonov based on the minimization of the stabilizing functional.
\end{abstract}

The calculation of integrals in the spatial integral equation is carried out exactly according to analytical formulas. Derivatives in the kernel of the equation were calculated both numerically and analytically, taking into account the new relations. The presence and influence on the computational process of specia points of the func-tions - derivatives of the kernel at the origin, where the continuity of the functions is violated and there is no
Research on the topic of the article is executed with support of grant RFBR I8-0I-00204.

Keywords: permanent magnets, magnetization, scalar magnetic potential, integral equation of magnetostatics, inverse problem, identification

single limit value. The calculation of induction, intensity and study of the influence of the shape of the magnetization characteristics. At the first stage of the solution by known experimental values of induction outside the volume of magnetic material the solution of the inverse problem is carried out and approximate values of magnetization in this volume are found. At the second stage, ac-cording to the known characteristic of magnetization in the volume, the values of induction and magnetic field strength are found in various ways. The main magnetization curve is calculated by the Langevin formula. The hysteresis loop is calculated from the selected range of magnetic in-tensity values according to the jils-Atterton model. The implementation of the method in terms of magnetization with different ratio of the number of cells of the magnet region and measurement points is considered. For the selected hysteresis loop, envelope loops are plotted at the top and bottom of the line. As a result of solving the equations, the corresponding minimum, maximum and average values of the intensity, as well as the induction of the field are found. This makes it possible to estimate the error when re-placing the hysteresis curve with the main characteristic of magnetization. The identification of magnetization of a rectangular permanent magnet on a ferromagnetic plate is considered as a model problem. It is stated that for small numbers of measurements the detailed picture of the field is found with a large error, which requires caution in the inter-pretation of the experimental data. The influence of the choice of measurement points location at random measurement errors is also significant, especially at a small number of measurement points. The dependence of the solution accuracy on the regularization parameter values is inves-tigated. Shows the influence of the location of measurement points on the accuracy of the identification of the magnetic field. The influence of the hysteresis loop width on the corresponding range of magnetic field intensity values in solving the problem of magnetization identification is studied. The obtained results can also be used in solving the inverse problem for the system of ferromagnetic bodies and in test problems using other methods.

Information about authors:

Robert V. Harutyunyan, Moscow State Technical University named after NE Bauman, Ph.D., associate professor of the Department of Computation Mathematics and Mathematical Physics, Moscow, Russia

Для цитирования:

Арутюнян Р.В. Расчет намагниченности постоянных магнитов и оптимизация расположения точек измерений индукции при использовании метода интегральных уравнений с учетом гистерезиса // Т-Соmm: Телекоммуникации и транспорт. 2020. Том |4. №6. C. $39-47$.

For citation:

Harutyunyan R.V. (2020) Calculation of magnetization of permanent magnets and optimization of the location of induction measurement points using the method of integral equations with hysteresis. T-Comm, vol. 14, no.6, Pp. 39-47. (in Russian) 


\section{Introduction}

Advances in the creation of permanent magnets with high energy density based on somarium cobalt (SmCo) and neodymium iron boron $(\mathrm{NdFeB})$ allowed to create electrical devices with permanent magnets, widely used in various fields. Electric motors with permanent magnets, having higher efficiency, having a smaller volume and weight per unit of power used in the locomotive building, industrial automation systems, robots and manipulators, feed drives and the main motion of machine tools, jig devices, printers and plotters, packaging printing machines, precision tracking systems, winding and tape drive mechanisms, aircraft and medical equipment and other electrical devices. Due to the ability to create a magnetic field without external energy sources, permanent magnets are often used in the design of energy-saving devices.

At the same time, devices with permanent magnets have one important technological feature associated with the risk of their failure due to local demagnetization of magnets. The reasons for demagnetization can be as follows: current surge in the winding, overheating, mechanical effects. The presence of at least one of these factors can lead to partial or complete loss of properties of permanent magnets, power loss and even failure of the electrical device. If such situations occur, to analyze the impact of negative factors on the operation of the device, it is necessary to assess the state of the permanent magnet by studying the distribution of magnetization in its volume. As a rule, magnetization cannot be measured directly, but it can be determined indirectly by first measuring the values of magnetic induction in the air gap of the device or in the surrounding magnet space, and then, using these values, solve the problem of determining the magnetization. Problems of this type belong to the inverse class. The corresponding problems can be solved using numerical experiments, as a result of the analysis of the magnetic field taking into account the local demagnetization of permanent magnets, or as a result of evaluation of their magnetic state during operation by the results of indirect measurements of the field.

The article proposes the development of the method for estimating the magnetization of permanent magnets by the known distribution of the magnetic field in the surrounding space, which differs from the known methods in that it allows to take into account the presence of soft magnetic ferromagnetic materials with known characteristics.

The main objective of the study is to determine the conditions for the applicability of the modification of the previously developed numerical-experimental method for assessing the magnetization of permanent magnets for the diagnosis of electrical devices with permanent magnets in practice [1]. For this purpose, the influence of neglect in the mathematical model of the magnetic field by the magnetic hysteresis of the frame material of the electrical device on the accuracy of the result of the inverse problem of identification of the magnetization of permanent magnets is investigated. We performed a series of numerical experiments, intended to establish the deviation of the calculated characteristics of the field in the magnetic material depending on the choice of the curves of magnetization within the area of the hysteresis loop of the material of the frame of the diagnosed electrical devices.

The approach applied in the article to the problem of identification of the magnetic state of the system of permanent magnets and ferromagnets is based on the use of the corresponding integral equation of magnetostatics [1-10, 17-20].

As a rule, in the practice of magnetic flaw detection measurement of magnetic induction in order to identify the state of the electrical device with permanent magnets is made with the current off, or the field created by these currents in operating modes is relatively small compared to the field of permanent magnets. For these reasons, the presence of current windings was not taken into account in mathematical modeling. It is assumed that the magnetic system consists of permanent magnets and structural parts of ferromagnetic materials with known characteristics.

\section{The main relations of the research method 2.1. Identification of the magnetization}

Magnetization is associated with the induction and magnetic field strength according to the vector ratio: $\vec{M}=\vec{B} / \mu_{0}-\vec{H}$. In a non-magnetic medium $\vec{B}=\mu_{0} \vec{H}$, in a ferromagnetic and permanent magnet $\vec{B}=\mu_{0}(\vec{H}+\vec{M})$. For a stationary field is determined by the scalar magnetic potential: $\vec{H}=-\nabla \varphi$. We assume that at infinity the potential is zero.

The volume of the magnetic material is divided into cells (elementary parallelepipeds), then the intensity is recorded as [1]:

$$
\begin{aligned}
& \vec{H}(Q)=\frac{1}{4 \pi} \sum_{j=1}^{N_{0}}\left[\left(\int_{S_{x 2}^{(j)}} \frac{\vec{r}_{P Q} d S_{P}}{r_{P Q}^{3}}-\int_{S_{x 1}^{(j)}} \frac{\vec{r}_{P Q} d S_{P}}{r_{P Q}^{3}}\right) M_{x}^{(j)}+\right. \\
& +\left(\int_{S_{y 2}^{(j)}} \frac{\vec{r}_{P Q} d S_{P}}{r_{P Q}^{3}}-\int_{S_{y 1}^{(j)}} \frac{\vec{r}_{P Q} d S_{P}}{r_{P Q}^{3}}\right) M_{y}^{(j)}+ \\
& \left.+\left(\int_{S_{z 2}^{(j)}} \frac{\vec{r}_{P Q} d S_{P}}{r_{P Q}^{3}}-\int_{S_{z 1}^{(j)}} \frac{\vec{r}_{P Q} d S_{P}}{r_{P Q}^{3}}\right) M_{z}^{(j)}\right],
\end{aligned}
$$

where the cell surface is the Union of faces $S_{\text {Пм }}=S_{X_{1}} \cup S_{X_{2}} \cup S_{Y_{1}} \cup S_{Y_{2}} \cup S_{Z_{1}} \cup S_{Z_{2}}$ with normal

$$
\begin{aligned}
& \vec{n}_{x 1}=(-1,0,0), \vec{n}_{x 2}=(1,0,0), \vec{n}_{y 1}=(0,-1,0), \\
& \vec{n}_{y 2}=(0,1,0), \vec{n}_{z 1}=(0,0,-1), \vec{n}_{z 2}=(0,0,1)
\end{aligned}
$$

The coordinates of the cell vertices are denoted as:

$$
\left(x_{i}^{(j)}, y_{i}^{(j)}, z_{i}^{(j)}\right), i=1,2 ; j=1, \ldots, N_{0} .
$$

Induction $B$ is related to the intensity $H$ in a non-magnetic medium in the form:

$$
\vec{B}(Q)=\mu_{0} \vec{H}(Q)=\mu_{0} \sum_{j=1}^{N_{0}} \vec{H}^{(j)}(Q),
$$

where summation is carried out on all cells of the volume of the magnetic material. Multiply (2) by the normal vector $\vec{n}_{Q}$ to the volume surface:

$$
\mu_{0} \sum_{j=1}^{N_{0}} \vec{H}^{(j)}(Q) \vec{n}_{Q}=\vec{B}_{Q} .
$$

As $Q$ we choose the points $Q_{i}$ where the induction $\vec{B}\left(Q_{i}\right)$ is 
known, and as $\vec{n}_{Q}$ the ortha of the Cartesian coordinate system. Using the expression (1), we obtain the SLAE for the solution of the integral equation of the magnetization identification problem:

$$
\begin{aligned}
& \frac{\mu_{0}}{4 \pi} \sum_{j=1}^{N_{0}}\left[\left(\int_{S_{x 2}^{(j)}} \frac{\vec{r}_{P Q} \vec{n}_{Q} d S_{P}}{r_{P Q}^{3}}-\int_{S_{x 1}^{(j)}} \frac{\vec{r}_{P Q} \vec{n}_{Q} d S_{P}}{r_{P Q}^{3}}\right) M_{x}^{(j)}+\right. \\
& +\left(\int_{S_{y 2}^{(j)}} \frac{\vec{r}_{P Q} \vec{n}_{Q} d S_{P}}{r_{P Q}^{3}}-\int_{S_{y 1}^{(j)}} \frac{\vec{r}_{P Q} \vec{n}_{Q} d S_{P}}{r_{P Q}^{3}}\right) M_{y}^{(j)}+ \\
& \left.+\left(\int_{S_{z 2}^{(j)}} \frac{\vec{r}_{P Q} \vec{n}_{Q} d S_{P}}{r_{P Q}^{3}}-\int_{S_{z 1}^{(j)}} \frac{\vec{r}_{P Q} \vec{n}_{Q} d S_{P}}{r_{P Q}^{3}}\right) M_{z}^{(j)}\right]= \\
& =\vec{B}(Q) \vec{n}_{Q}, Q=Q_{i}, i=1, N_{1} . \\
& \vec{H}=\sum_{j=1}^{N}-\nabla a_{j}(Q) M_{j} .
\end{aligned}
$$

We write SLAE (3) in matrix form:

$$
A M_{h}=b_{h}, M_{h}=\left\{M_{j}\right\}_{j=1}^{N}, b_{h}=\left\{B_{n i}\right\}_{i=1}^{N_{1}}, N=3 N_{0},
$$

where

$M_{3 j-2}=M_{x}^{(j)}, M_{3 j-1}=M_{y}^{(j)}, M_{3 j}=M_{z}^{(j)}, j=1, \ldots, N_{0} ;$

In the practice of measuring the values of magnetic induction are with some error $\varepsilon$ :

$$
\begin{aligned}
& \tilde{B}_{n i} \approx B_{n}\left(Q_{i}\right), \tilde{B}_{n i}=B_{n}\left(Q_{i}\right)\left(1+\varepsilon_{B}^{(i)}\right), \\
& A \tilde{M}_{h}=\tilde{b}_{h}, \tilde{b}_{h}=\left\{\tilde{B}_{n i}\right\}_{i=1}^{N_{1}},
\end{aligned}
$$

The number of measurement points $N_{1}$ is not always consistent with the number of cells in the domain partition $N_{0}$, so the

SLAE matrix (3) is generally non-square. For the regularization of the SLAE operator, the method of A. N. Tikhonov is usually applied. It based on the minimization of the stabilizing functional $\left\|A \tilde{M}_{h}-\tilde{b}_{h}\right\|^{2}+\sigma\left\|\tilde{M}_{h}\right\|^{2} \rightarrow \min _{\tilde{M}_{h}}$ with a regularization parameter $\sigma$ that leads to a SLAE $[1,5,9,12,16]$ :

$$
\sigma \tilde{M}_{h}+A^{\mathrm{T}} A \tilde{M}_{h}=A^{\mathrm{T}} \tilde{b}_{h} .
$$

If $\left\|\varepsilon_{B}\right\| \rightarrow 0$, then the optimal value of the regularization parameter $\sigma \rightarrow 0$, and the solution of SLAE (6) converges to the exact one.

The calculation of integrals in (3) is carried out exactly by analytical formulas:

$$
\begin{aligned}
& \int_{S_{z_{Q}}} \frac{d S_{P}}{r_{P Q}}=\int_{x_{1}}^{x_{2}} \int_{y_{1}}^{y_{2}} \frac{d x_{P} d y_{P}}{\sqrt{\left(x_{P}-x_{Q}\right)^{2}+\left(y_{P}-y_{Q}\right)^{2}+\left(z_{P}-z_{Q}\right)^{2}}}= \\
& =\int_{x_{1}-x_{Q}}^{x_{2}-x_{Q}} \int_{y_{1}-y_{Q}-y_{Q}} \frac{d x d y}{\sqrt{x^{2}+y^{2}+z^{2}}}=f\left(x_{2}-x_{Q}, y_{2}-y_{Q}, z\right)- \\
& -f\left(x_{1}-x_{Q}, y_{2}-y_{Q}, z\right)-f\left(x_{2}-x_{Q}, y_{1}-y_{Q}, z\right)+ \\
& +f\left(x_{1}-x_{Q}, y_{1}-y_{Q}, z\right), z=z_{P}-z_{Q}
\end{aligned}
$$

$$
\begin{aligned}
& f(x, y, z)=x \ln (r+y)+y \ln (r+x)- \\
& -z \operatorname{arctg}[x y /(z r)]+z \operatorname{arctg}(x / z)-x, \\
& r=\sqrt{x^{2}+y^{2}+z^{2}}
\end{aligned}
$$

Derivatives in (3) were calculated both numerically and analytically taking into account the expressions:

$$
\begin{aligned}
& \partial f / \partial x=-1+\left(1+x^{2} z^{-2}\right)^{-1}+y r^{-1}+x^{2} r^{-1}(r+y)^{-1}- \\
& -y r^{-1}\left(1-x^{2} r^{-2}\right)\left(1+x^{2} y^{2} z^{-2} r^{-2}\right)^{-1}+\ln (r+y) \\
& \partial f / \partial y=x r^{-1}+y^{2} r^{-1}(r+x)^{-1}- \\
& -x r^{-1}\left(1-y^{2} r^{-2}\right)\left(1+x^{2} y^{2} z^{-2} r^{-2}\right)^{-1}+\ln (r+x) \\
& \partial f / \partial z=-\operatorname{arctg}\left(x y z^{-1} r^{-1}\right)-x z^{-1}\left(1+x^{2} z^{-2}\right)^{-1}+ \\
& +x y z r^{-1}\left(z^{-2}+r^{-2}\right)\left(1+x^{2} y^{2} z^{-2} r^{-2}\right)^{-1}+ \\
& +x z r^{-1}(r+y)^{-1}+y z r^{-1}(r+x)^{-1}+\operatorname{arctg}\left(x z^{-1}\right) .
\end{aligned}
$$

It should be noted that there are special points in the recorded functions-derivatives at the origin, where the continuity of the functions is violated and there is no single limit value. The adverse effect of these features on the computational process can be affected if some two coordinates of the measurement point coincide with the corresponding coordinates of the vertices of some cells of the volume.

\subsection{Calculation of induction, intensity and study of the influence of the shape of the magnetization characteristics}

At the first stage of the solution, the inverse problem (3)-(6) is solved by the known experimental values of induction outside the volume of the magnetic material and the approximate values of magnetization in this volume are found.

At the second stage, according to the known characteristic of magnetization in the volume, the values of induction and magnetic field strength are found in various ways. The main magnetization curve is calculated by the Langevin formula

$M_{f}(H)=M_{s}(\operatorname{cth}(H / a)-a / H)$, parameters $M_{s}, a$ determined by the material. The hysteresis loop is calculated from the selected range of magnetic intensity values $\left(-H_{\mathrm{m}}, H_{\mathrm{m}}\right)$ according to the Giles-Atherton model [22] (Fig. 1):

$$
\begin{aligned}
& d M / d H=\left(M_{f}(H)-M\right) / k d\left(H_{t}, M_{f}(H)-M\right)+c d M_{f} / d H \\
& d M_{f} / d H=M_{s}\left(-\operatorname{sh}^{-2}(H / a)+a / H^{-2}\right), \\
& d\left(H_{t}, \Delta\right)=\left\{\begin{array}{l}
-1, H_{t}<0, \Delta \leq 0 \\
0, H_{t} \Delta<0 \\
1, H_{t}>0, \Delta \geq 0
\end{array}\right.
\end{aligned}
$$

where $H_{t}$ is the time partial derivative of the field strength.

The values of the model parameters Giles-Atherton for electrotechnical-grade steel $Э 330 \mathrm{~A}$ equal to $M_{s}=1648136,0$; $a=55,2 ; k=67,5 ; c=0,0186$ [22].

For the selected hysteresis loop envelope lines are built (Fig. 1), which equations have the form: $M_{f}^{ \pm}(H)=M_{f}(H) \pm \Delta B / \mu_{0}$. For Fig. 1 these envelopes are marked with numbers 1 and 2. 
The arrows in the figure show the direction of the field strength change. At the initial time $t$, the intensity at the considered point of the magnetic material is zero. Then it increases to the selected maximum value (Fig. 1 is 500 a / m, curve 3), after which the stress decreases to $-500 \mathrm{a} / \mathrm{m}$ (the upper part of the curve 4 ) and then increases again to the maximum value (the lower part of the curve 4).

As a re 1 t of solving the equations $M_{f}(H)=M, M_{f}^{ \pm}(H)=M$, the corresponding minimum, maximum and average values of the field strength $H$ are found, as well as by the field induction formula $\vec{B}=\mu_{0}(\vec{H}+\vec{M})$. This makes it possible to estimate the error when replacing the hysteresis curve with the main characteristic of magnetization.

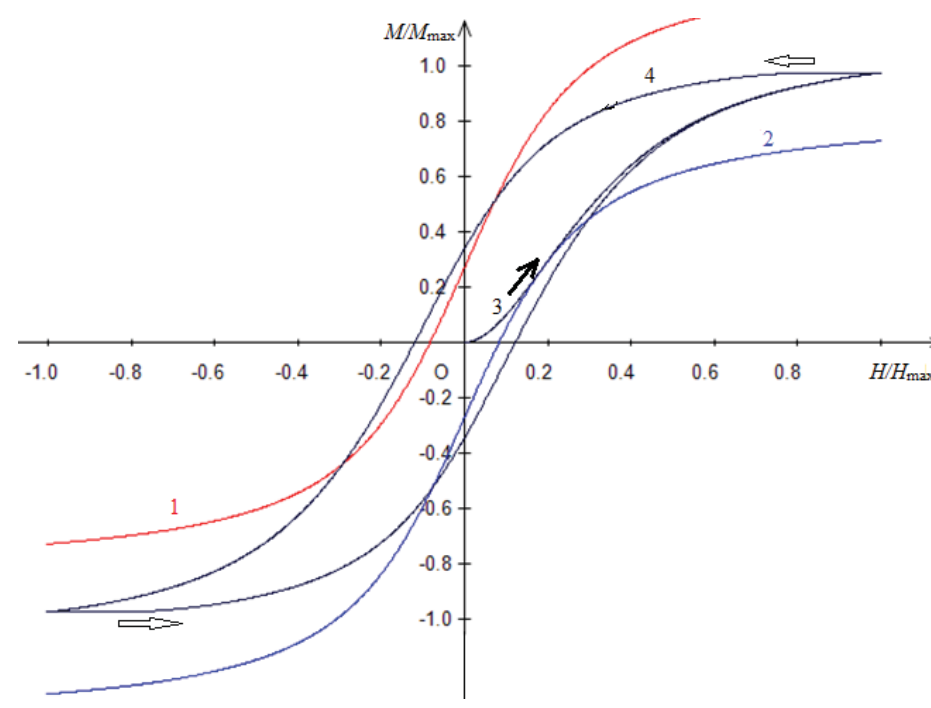

Fig. 1. The hysteresis loop and the corresponding envelope curves

\subsection{Optimization of the location of the measurement points induction}

it is of great practical importance, as it allows to obtain a better solution to the problem of identification of magnetization. The authors investigated several approaches to the placement of measurement points: uniform (with a constant step for each coordinate) uniformly distributed random arrangement, quasirandom, approximately uniform (low-dispersed) distribution based on the sequence of Halton, optimization Monte Carlo optimization method alternating-variable descent method. In the latter case, MINV optimization program was used [21].

\section{Simulation result}

\subsection{Identification of the magnetization}

The identification of magnetization of a rectangular permanent magnet is considered as a model problem $\left(0<x<L_{x} ; 0<y<L_{y} ; L_{f}<z<L_{z}\right)$ on a ferromagnetic plate $\left(0<x<L_{x} ; 0<y<L_{y} ; 0<z<L_{f}\right)$.

The sizes varied within the following limits:

$$
L_{x}=0.01 \ldots 0.1 ; L_{y}=0.01 \ldots 0.1 ; L_{z}=0.01 \ldots 0.1 ; L_{f}=0.005 \ldots 0.05 \text {. }
$$

The number of partitions on the coordinate axes: $n_{x}, n_{y}, n_{z}=2.5$; the number of cells of the volume partition $N_{0}=n_{x} n_{y} n_{z}$ was chosen equal to 8.125. Cell size $h_{x}=L_{x} / n_{x}, h_{y}=L_{y} / n_{y}, h_{z}=L_{z} / n_{z}$. The volume of the permanent magnet is assumed to be uniformly magnetized along the $\mathrm{OZ}$ axis with maximum residual induction $B_{r}=1 \mathrm{~T}$ : $M_{x}^{(j)}=0, M_{y}^{(j)}=0, M_{z}^{(j)}=B_{r} / \mu_{0}, j=N_{f}+1, \ldots, N_{0}$. The values of the magnetization in the ferromagnetic base of a priori unknown. It is assumed that the measurements of magnetic quantities were carried out with a random uniformly distributed relative error $\varepsilon=10^{-2}(1 \%)$, the measurement points were located at a distance from the surface of the volume of the magnetic material by the size of the cell of the region. Above the faces, the location of the measurement points was chosen randomly, but evenly distributed. Various options are considered: a) for each face, the number of measurement points is the same; b) measurements are carried out only near the lower and upper faces. Using the designated standard $s=\sqrt{\left\langle\left(\tilde{M}_{j} / M_{j}\right)^{2}\right\rangle-\left\langle\tilde{M}_{j} / M_{j}\right\rangle^{2}}$ (standard deviation) relationship the exact values of the coordinates of the magnetization vector to the appropriate approximate. Angle brackets indicate statistical averaging. Ideally, this ratio is one and the deviation is zero.

The results of calculations with $n_{x}=n_{y}=4, n_{z}=8$ are presented in table. 1 (measurements near the lower and upper faces of the magnetic material area). The number of measurement points equals the number of unknown values of the magnetization in the cells of the partitioning of the volume $N_{1}=3 n_{x} n_{y} n_{z}=384$. The dimensions of the area: $L_{x}=0.1 ; L_{y}=0.1 ; L_{z}=0.1 ; L_{f}=0.05$.

For Fig. 1 in relative coordinates (scales: on the abscissa axis $H_{\max }=250$, on the ordinate axis $-M_{\max }=1139407,85093562$ ) for the described initial data the exact and calculated values of magnetization $M_{z}$ in the centers of cells at $\sigma=10^{-17}$ are presented.

Table 1

Characteristics of solutions for different values of the regularization parameter

\begin{tabular}{|c|c|c|c|c|c|}
\hline$\sigma$ & $\left\langle\tilde{M}_{j} / M_{j}\right\rangle$ & $\sqrt{\left\langle\left(\tilde{M}_{j} / M_{j}\right)^{2}-1\right\rangle}$ & $S$ & $\min \tilde{M}_{j} / M_{j}$ & $\max \tilde{M}_{j} / M_{j}$ \\
\hline 0 & 0.0 & 1.00 & 0.01 & -0.02 & 0.12 \\
\hline $5^{*} 10^{-18}$ & 1.04 & 0.17 & 0.17 & 0.61 & 1.73 \\
\hline $10^{-17}$ & 1.03 & 0.11 & 0.11 & 0.70 & 1.37 \\
\hline $5^{*} 10^{-17}$ & 1.05 & 0.12 & 0.11 & 0.87 & 1.36 \\
\hline $10^{-16}$ & 1.07 & 0.17 & 0.16 & 0.78 & 1.50 \\
\hline
\end{tabular}

For Fig. 2 in the same relative coordinates as in Fig. 1, for the described initial data, the minimum, maximum and average values of the field strength $H_{z}$ and the calculated values of the magnetization $M_{z}$ in the centers of the cells at $\sigma=10^{-17}, x=L_{x} / 2, y=L_{y} / 2$ are presented. 


\section{ELECTRONICS. RADIO ENGINEERING}

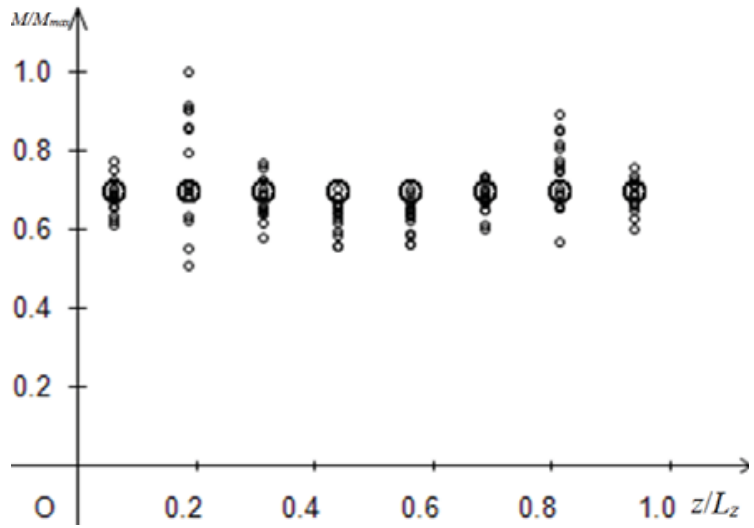

Fig. 1. Accurate and calculated values of the magnetization $M_{z}$ in the cell centers with $\sigma=10^{-17}$ (see also data table. 1)

The largest size of the circles in Fig. 2 correspond to the magnetization (its distribution is shown throughout the volume of the magnetic material, and for the strength - only for the ferromagnetic base). The width of the hysteresis loop is characterized by $\Delta B=0,5 \mathrm{~T}$. Fig. 2 qualitatively illustrates the error when replacing the hysteresis curve with the main characteristic of magnetization. The effect of the hysteresis loop width in this example on the field induction is much smaller, since the intensity is several orders of magnitude less than the magnetization.

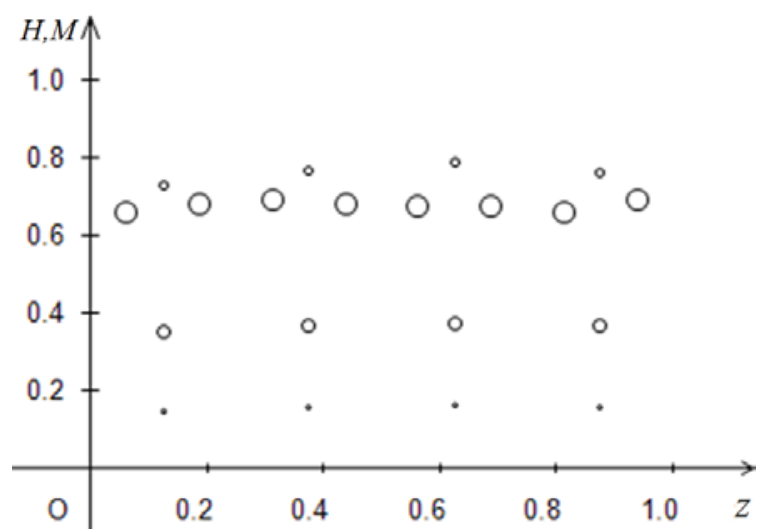

Fig. 2. Minimum, maximum and average values of the field strength $H_{z}$ and magnetization $M_{z}$ in the centers of the cells at $\sigma=10^{-17}, x=L_{x} / 2, y=L_{y} / 2$ (see also data to table. 1)

The influence of the number of measurement points is illustrated in the table. 2 .

Table 2

Results for different number of measurement points at $\sigma=10^{-17}$

\begin{tabular}{|c|l|c|c|c|c|}
\hline$N$ & $\left\langle\tilde{M}_{j} / M\right.$ & $\sqrt{\left\langle\left(\tilde{M}_{j} / M_{j}\right)^{2}\right.}$ & $S$ & $\min \tilde{M}_{j} / M_{j}$ & $\max \tilde{M}_{j} / M_{j}$ \\
\hline 100 & 1 & 0.39 & 0.31 & 0.66 & 2.14 \\
\hline 75 & 1. & 0.38 & 0.30 & 0.61 & 1.91 \\
\hline 50 & 1.38 & 0.54 & 0.39 & 0.53 & 2.67 \\
\hline 25 & 2. & 2.09 & 1.73 & -5.36 & 9.53 \\
\hline
\end{tabular}

For small numbers of measurements, the detailed picture of the field is found with a large error, which requires caution in the interpretation of the experimental data. This fact is illustrated in Fig. 3 and 4.

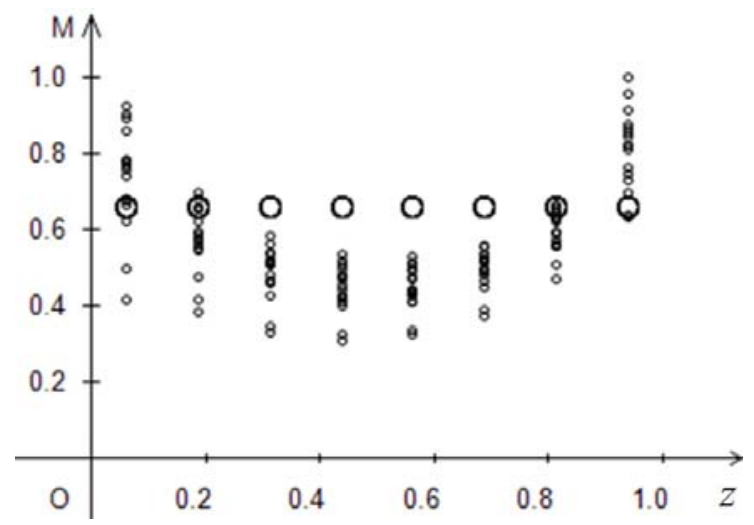

Fig. 3. Accurate and calculated values of the magnetization $M_{z}$ in the centres of cells when $\sigma=10^{-17}, x=L_{x} / 2, y=L_{y} / 2, N_{1}=100$ (see also data table. 2)

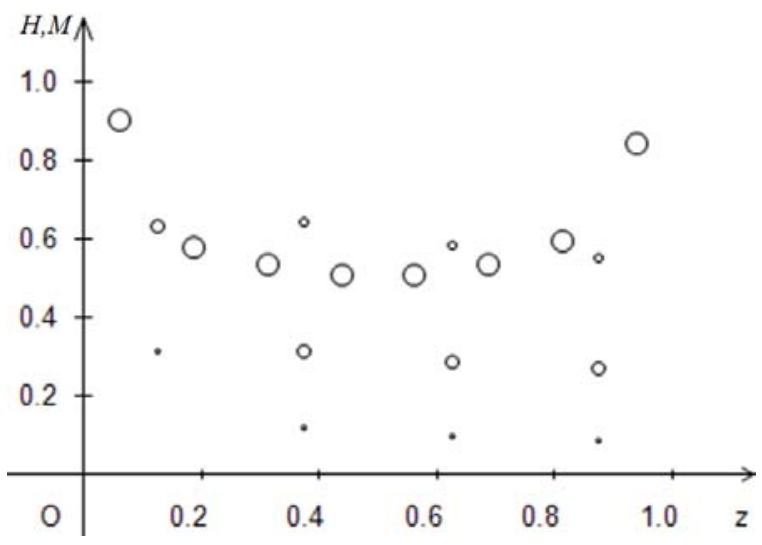

Fig. 4. Minimum, maximum and average values of the field strength $H_{z}$ and magnetization $M_{z}$ in the centers of the cells at $\sigma=10^{-17}, x=L_{x} / 2, y=L_{y} / 2, N_{1}=100$ (see also data table. 2)

The influence of the choice of measurement points location at random measurement errors is also significant, especially at a small number of measurement points. Thus, for a sample of 20 series of measurements (50 in each), the parameter change intervals were:

$$
\begin{aligned}
& \left\langle\tilde{M}_{j} / M_{j}\right\rangle=-18,57 \ldots 1,84 ; \sqrt{\left\langle\left(\tilde{M}_{j} / M_{j}\right)^{2}-1\right\rangle}= \\
& =0,54 \ldots 227,12 ; s=0,39 \ldots 226,27 ; \min \tilde{M}_{j} / M_{j}= \\
& =-2568,54 \ldots 0,62 ; \max \tilde{M}_{j} / M_{j}=2,43 \ldots 47,92 .
\end{aligned}
$$

\subsection{Optimizing the location of measurement points}

The magnetic system of the same as in the previous point of a configuration with the sizes was considered:

$L_{x}=0,01 ; L_{y}=0,01 ; L_{z}=0,01 ; L_{f}=0,005$.

Parameters of magnetic material area splitting into cells: 


\section{ELECTRONICS. RADIO ENGINEERING}

$$
n_{x}=n_{y}=2, n_{z}=4 \text {. }
$$

It was assumed that the measurements are carried out only over the upper face of the permanent magnet at a distance of the cell size. Number of measurement points $N_{1}=12$. Inaccuracy of measurements $1 \%$ (random and evenly distributed). A permanent magnet was magnetized along the axis of the applicator that con with the residual induction $B_{r}=1 \mathrm{~T}$.

The value of the mean square relative deviation of the calculated magnetization from the exact solution was optimized $\sqrt{\left\langle\left(\tilde{M}_{j} / M_{j}\right)^{2}-1\right\rangle}$.

Geometric constraint $0 \leq x \leq L_{x}, 0 \leq y \leq L_{y}$ taken into account by the method of fines. Points of local minima were found with accuracy $10^{-5} \ldots 10^{-2}$. All solutions are symmetric with respect to the axes of symmetry of the rectangle $0 \leq x \leq L_{x}, 0 \leq y \leq L_{y}$.

The best solution is: $x_{1}=0,00315 ; y_{1}=0,00322 ; x_{2}=10^{-7} ; y_{2}=10^{-6}$; $x_{3}=0,00546 ; y_{3}=0,00499$. Other points $x_{4}, y_{4}, \ldots, x_{12}, y_{12}$ are calculated on the basis of the symmetry of the solution with respect to the axes of symmetry of the rectangle. Solution features: $\left\langle\tilde{M}_{j} / M_{j}\right\rangle=0,93 \sim 1 ; \sqrt{\left\langle\left(\tilde{M}_{j} / M_{j}\right)^{2}-1\right\rangle}=0,2061 ; s=0,19$; $\min \tilde{M}_{j} / M_{j}=0,65 ; \max \tilde{M}_{j} / M_{j}=1,19$.

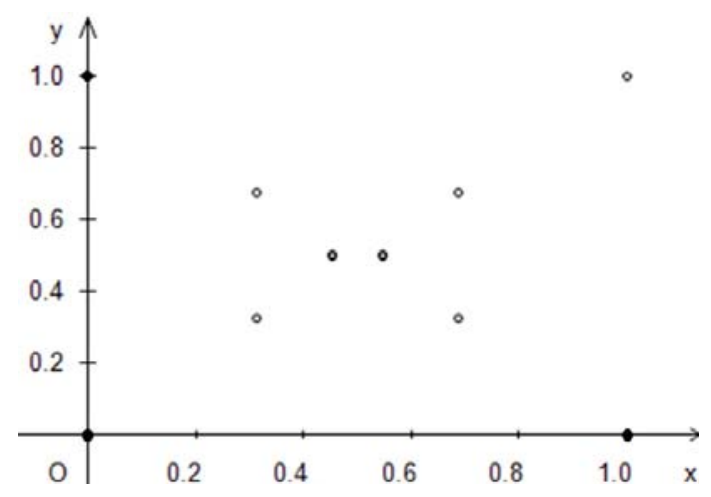

Fig. 5. Induction measurement points (best option)

A similar quality solution is shown in Fig. 6.
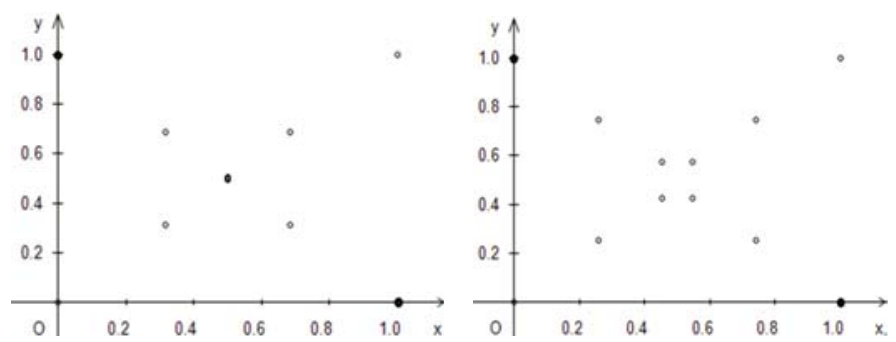

Fig. 6. Induction measurement points (quasi-optimal variants) Characteristics of the local optimum in Fig. 7: $\left\langle\tilde{M}_{j} / M_{j}\right\rangle=0,92$;

$$
\begin{gathered}
\sqrt{\left\langle\left(\tilde{M}_{j} / M_{j}\right)^{2}-1\right\rangle}=0,21545 ; s=0,20 ; \min \tilde{M}_{j} / M_{j}=0,63 ; \\
\max \tilde{M}_{j} / M_{j}=1,21 .
\end{gathered}
$$

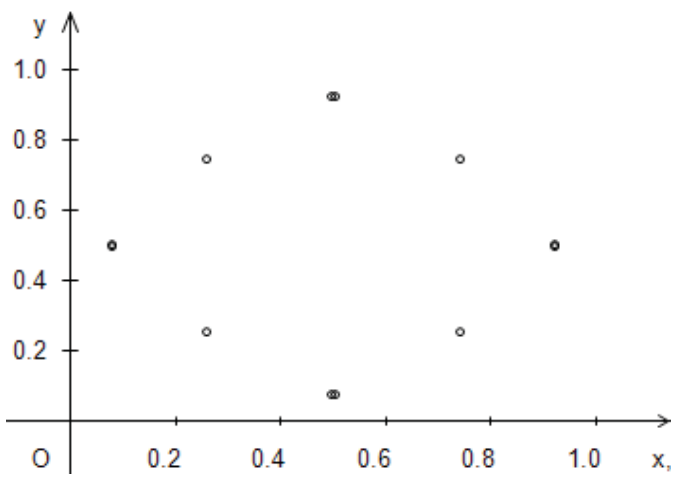

Fig. 7. Measurement points of induction (local optimum)

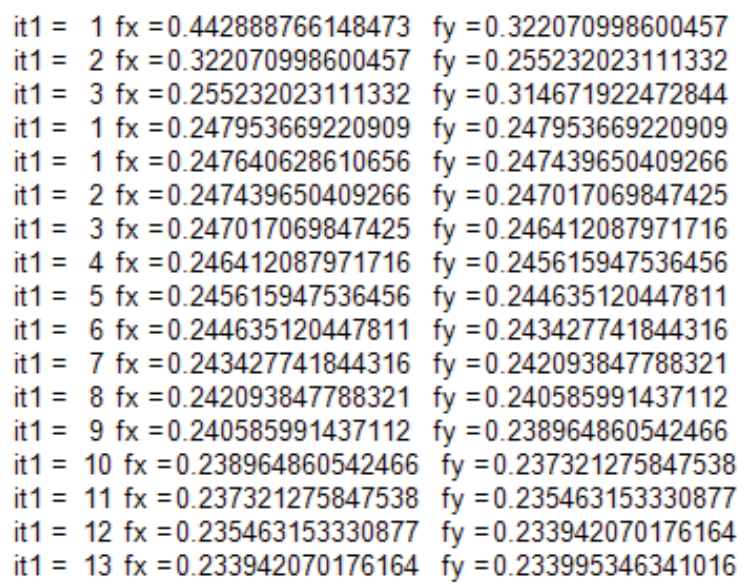

Fig. 8. Iterations during optimization by MINV program
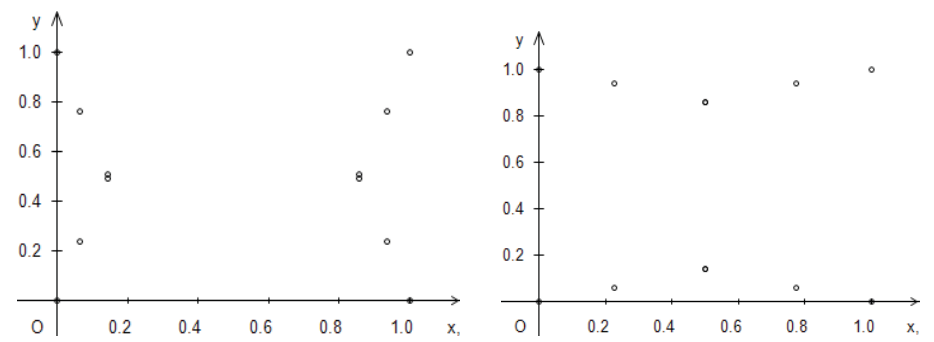

Fig. 7. Other types of local Optima

Halton sequence (quasi Monte Carlo) leads to the following results (Fig. 8, left): characteristics of the local optimum in Fig. 8: $\left\langle\tilde{M}_{j} / M_{j}\right\rangle=0,67 ; \quad \sqrt{\left\langle\left(\tilde{M}_{j} / M_{j}\right)^{2}-1\right\rangle}=0,52 ; \quad s=0,40 ;$ $\min \tilde{M}_{j} / M_{j}=0,24 ; \max \tilde{M}_{j} / M_{j}=1,56$.
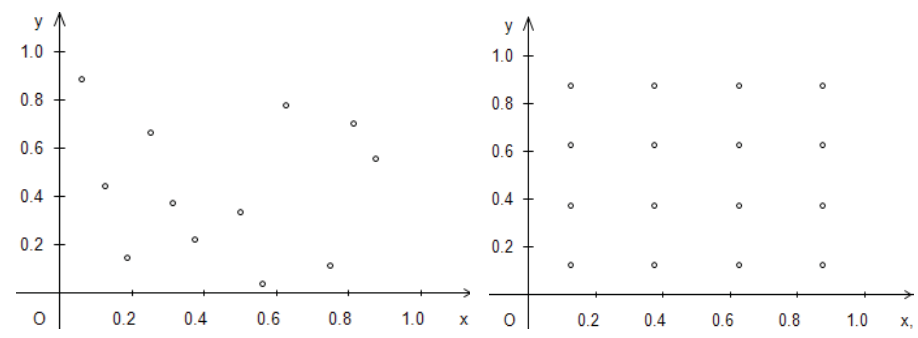

Fig. 8. Quasimonte-Carlo solution (left). Rectangular grid (right) 
The traditional arrangement of points according to a rectangular grid leads to similar quasimonte-Carlo results. Characteristics of the solution at the location of the points shown in Fig. 8: $\left\langle\tilde{M}_{j} / M_{j}\right\rangle=0,69 ; \quad \sqrt{\left\langle\left(\tilde{M}_{j} / M_{j}\right)^{2}-1\right\rangle}=0,55 ; \quad s=0,45 ;$ $\min \tilde{M}_{j} / M_{j}=0,25 ; \max \tilde{M}_{j} / M_{j}=1,46$

Thus, optimization by the coordinate descent method leads to an improvement of the solution by more than 2 times. Monte Carlo and quasi Monte Carlo methods are ineffective in the problem under consideration.

\section{Conclusion}

Researched and modified the method of identifying the magnetic state of a secluded permanent magnet on a ferromagnetic base on the famous picture of the field in the surrounding space taking into account the effect of the hysteresis characteristics of the magnetization of the base. In the method used to replace integration over volume elements of the split permanent magnets by integrating the edge. The integrals in the matrix of the coefficients of the SLOUGH are accurately analytically derived a new expression without discontinuous functions. It is assumed that the error occurs only when measurements in the region of nonmagnetic material induction values.

The implementation of the method in terms of magnetization with different ratio of the number of cells of the magnet region and measurement points is considered.

The dependence of the solution accuracy on the regularization parameter values is investigated.

The influence of the hysteresis loop width on the corresponding range of magnetic field intensity values in solving the problem of magnetization identification is studied.

Shows the influence of the location of measurement points on the accuracy of the identification of the magnetic field.

Addressed the topic of optimization of the location of the measurement points of the magnetic field. The efficiency of a number of optimization methods in this problem is investigated, among which the best was the method of coordinate descent. The use of optimization can greatly improve the quality of the solution with a minimum number of measurements.

The obtained results can also be used in solving the inverse problem for the system of ferromagnetic bodies and in test problems using other methods.

Research on the topic of the article is executed with support of grant RFBR 18-01-00204. We express our gratitude to Professor Nekrasov for the comprehensive assistance in the preparation of the article.

\section{References}

1. Denisov P.A. (2016). The Solving of direct and inverse problems of the analysis of the magnetic field of electrical devices with permanent magnets in their local demagnetization. Thesis for the degree of candidate of technical Sciences. Novocherkassk-2016. 119 p.

2. Cherkasova O.A. The Study of the magnetic field of a permanent magnet with the help of computer simulation. http://hmm.sgu.ru/sites/default/files/issledovanie_magnitnogo_polya_postoy annogo_magnita_s_pomoshchyu_kompyuternogo_modelirovaniya.pdf.

3. Matyuk V.F., Churilo V.R., Strelyukhin A.B. (2003). Numerical simulation of the magnetic state of a ferromagnet in an inhomogeneous constant field method of spatial integral equations. Testing. 2003. No. 8. P. 71-84. http://naukarus.com/chislennoe-modelirovanie-magnitnogo- sostoyaniya-ferromagnetika-v-neodnorodnom-postoyannom-polemetodom-prostranstvennyh-i.

4. Ignat'ev V.K., Orlov A.A. (2014). Inverse magneto-static problem for a ferromagnetic/ Science and education. January 1, 2014 P. 300-324. http://technomagelpub.elpub.ru/jour/article/viewFile/467/469.

5. Zhirkov V.F., Novikov K.V., Sushkova L.T. (2005). Solution of the inverse problem of magnetostatics by the method of Tikhonov regularization. http://autex.spb.su/download/dsp/dspa/dspa2005/t1/74.pdf.

6. Dyakin V.V., Kudryashova O.V., Raevsky V.Y. (2017). To the question of the correctness of direct and inverse problems of magnetostatics. Part 1. Defectoscopy. No. 7, 2017. P. 35-45. https://www.libnauka.ru/journal/defektoskopiya/defektoskopiya-2017-

7/voprosu-korrektnosti-pryamoy-i-obratnoy-zadach-magnitostatikichast-1-defektoskopiya.

7. Pechenkov A.N. (2007). Algorithms of calculations and modeling of direct and inverse problems of magnetostatic flaw detection and devices of technical magnetostatics. doctor of engineering. Author's abstract on competition of a scientific degree of the doctor of technical Sciences. 05.02.11-methods of control and diagnostics in mechanical engineering. Yekaterinburg. 2007. $42 \mathrm{p}$.

8. Zhidkov E.P., Perepelkin E.E. (2003). Behavior of the solution of the nonlinear problem of magnetostatics in the vicinity of the angular point of the ferromagnet / Math. Modeling. No. 15 (4). 2003. P. 77-84. http://www.mathnet.ru/links/8987cc5434c5f5d6fd5efd33fe58812b/mm4 71.pdf.

9. Solution of a nonlinear inverse problem of magnetostatics by regularization / E. p. Zhidkov, I. V. Kuts, R. V. Polyakova, etc. Dubna: JINR, 1988. 10 p.: count.; 22 see - (Rev. 'ed. in-t cores. research.; P1188-335). https://search.rsl.ru/ru/record/01001422197.

10. Shur M.L., Novoslugina A.P., Smorodinskii Ya. (2013). On the Inverse Problem of Magnetostatics/ Russian Journal of Nondestructive Testing, 2013, Vol. 49, No. 8, pp. 465-473. http://elar.urfu.ru/bitstream/10995/27292/1/scopus-2013-0456.pdf.

11. Shary S.P. Interval methods for regularization of ill-conditioned and ill-posed problems. Institute of computer technologies SB RAS Novosibirsk state University. XVIII all-Russian conference of young scientists on mathematical modeling and information technologies. http://conf.nsc.ru/files/conferences/ym2017/415381/Sharyi_SP-YM2017.pdf.

12. Denisov A.M. (1984). The method of equations of the 1-St genus in the Hilbert space. USSR Academy of sciences. 1984. Vol. 274. No. 3. P. 528-530.

15. Verlan A.F., Sizikov V.S. (1986). Integral equations: methods, algorithms, programs. Kyiv: Naukova Dumka. $128 \mathrm{p}$.

16. Trenogin V.A. (1980). Functional analysis. Moscow: Science. 495 p.

17. Dyakin V.V., Kudryashova O.V., and Raevskii V.Y. (2015). On the solution of the magnetostatic field problem in the case of magnetic permeability that is dependent on coordinates. Russian Journal of Nondestructive Testing. Vol. 51. No. 9. P. 554-562.

18. Krotov L.N. (2004). Modeling the inverse geometric problem of magnetostatics in magnetic control. Abstract. Diss. on competition of a scientific degree. educational article, Dr. of physics and mathematics. Sciences'. Perm. 2004. http://www.science.by/upload/iblock/915/ 915879eb2bc1677d493a2262187274b0.pdf.

19. Akishin P.G., Sapozhnikov A.A. (2014). The method of volumetric integral equations in problems of magnetostatics. Vestnik RUDN. Series: Mathematics, computer science, physics. No. 2. C. 310-315. https://cyberleninka.ru/article/n/metod-obyomnyh-integralnyhuravneniy-v-zadachah-magnitostatiki.

20. Arutyunyan R.V., Nekrasov S.A., Sredina P.B. (2018). Identification of the magnetization of constant magnets on the basis of the method of the scalar magnetic potential. News of higher educational institutions. Electromechanics. No. 6.

21. Germain-Lacour P., George P. L., Pister F., bézier, P. (1989). Mathematics and CAD. Moscow: Mir. $264 \mathrm{p}$.

22. enisov P. (2018). A description of the hysteresis loop using explicit expressions for the gils-Atherton model of the second level. News of higher educational institutions. Electromechanics. Vol. 61. No. 1. P. 6-12. 


\section{РАСЧЕТ НАМАГНИЧЕННОСТИ ПОСТОЯННЫХ МАГНИТОВ И ОПТИМИЗАЦИЯ РАСПОЛОЖЕНИЯ ТОЧЕК ИЗМЕРЕНИЙ ИНДУКЦИИ ПРИ ИСПОЛЬЗОВАНИИ МЕТОДА ИНТЕГРАЛЬНЫХ УРАВНЕНИЙ С УЧЕТОМ ГИСТЕРЕЗИСА}

Арутюнян Роберт Владимирович, Московский государственный технический университет имени Н.Э.Баумана, Москва, Россия, rob57@mail.ru

\section{Аннотация}

Предложено развитие метода оценки намагниченности постоянных магнитов по известному распределению магнитного поля в окружающем пространстве, отличающееся от известных методов тем, что позволяет учитывать присутствие магнитомягких ферромагнитных материалов с известными характеристиками. Применяемый в статье подход к решению задачи идентификации магнитного состояния системы постоянных магнитов и ферромагнетиков основан использовании соответствующего интегрального уравнения магнитостатики. Основной задачей исследования является определение условий применимости модификации разработанного ранее численно-экспериментального метода оценки намагниченности постоянных магнитов для диагностики электротехнических устройств с постоянными магнитами на практике. Для этого исследовано влияние пренебрежения в математической модели магнитного поля магнитным гистерезисом материала каркаса электротехнического устройства на точность результата решения обратной задачи идентификации намагниченности постоянных магнитов. Проведена серия численных экспериментов, имеющих целью установить величину отклонения рассчитываемых характеристик поля в области магнитного материала в зависимости от выбора кривых намагничивания в пределах области петли гистерезиса материала каркаса диагностируемого электротехнического устройства. При математическом моделирования наличие обмоток с током не учитывалось. Предполагается, что магнитная система состоит из постоянных магнитов и конструкционных частей из ферромагнитных материалов с известными характеристиками. Для регуляризации оператора СЛАУ применяется метод А.Н.Тихонова, основанный на минимизации стабилизируюшего функционала. Вычисление интегралов в пространственном интегральном уравнении осуществляется точно по аналитическим формулам. Производные в ядре уравнения вычислялись как численно, так и аналитически с учетом полученных новых соотношений. Отмечено наличие и влияние на вычислительный процесс особых точек у функций-производных ядра в начале координат, где непрерывность функций нарушается и отсутствует единственное предельное значение. Осуществляется вычисление индукции, напряженности и исследование влияния формы характеристики намагничивания. На первом этапе решения по известным экспериментальным значениям индукции вне объема магнитного материала осуществляется решение обратной задачи и находятся приближенные значения намагниченности в данном объеме. На втором этапе по известной характеристике намагничивания в объеме различными способами находятся значения индукции и напряженности магнитного поля. Основная кривая намагничивания вычисляется по формуле Ланжевена. По выбранному интервалу значений магнитной напряженности согласно модели Джилса-Аттертона вычисляется петля гистерезиса. Рассмотрена реализация метода в терминах намагниченности с различным соотношением количества ячеек разбиения области магнита и точек измерений. Для выбранной петли гистерезиса строятся огибающие петлю сверху и снизу линии. В результате решения уравнений находятся соответствующие минимальные, максимальные и средние значения напряженности, а также индукция поля. Это позволяет оценить погрешность при замене гистерезисной кривой на основную характеристику намагничивания. В качестве модельной задачи рассмотрена идентификация намагниченности прямоугольного постоянного магнита на ферромагнитной плите. Констатировано, что при малых числах измерений детальная картина поля находится с большой погрешностью, что требует осторожности при интерпретации данных экспериментов. Влияние выбора расположения точек измерений при случайном характере погрешностей измерений также значительно, особенно при малом количестве точек измерений. Исследована зависимость точности решения от значений параметра регуляризации. Показано влияние расположения точек измерений на точность идентификации магнитного поля. Изучено влияние ширины петли гистерезиса на соответствующий диапазон значений напряженности магнитного поля при решении задачи идентификации намагниченности. Полученные результаты могут использоваться также при решении обратной задачи для системы ферромагнитных тел и в тестовых задачах при использовании других методов.

Ключевые слова: постоянные магниты, намагниченность, скалярный магнитный потенциал, интегральное уравнение магнитостатики, обратная задача, идентификация.

\section{Литература}

І. Денисов П.А. Решение прямых и обратных задач анализа магнитного поля электротехнических устройств с постоянными магнитами при их локальном размагничивании. Диссертация на соискание ученой степени кандидата технических наук. Новочеркасск, 2016. 119 с.

2. Черкасова О.А. Исследование магнитного поля постоянного магнита с помощью компьютерного моделирования.

http://hmm.sgu.ru/sites/default/files/issledovanie_magnitnogo_polya_postoyannogo_magnita_s_pomoshchyu_kompyuternogo_modelirovaniya.pdf

3. Матюк В.Ф., Чурило В.Р., Стрелюхин А.В. Численное моделирование магнитного состояния ферромагнетика в неоднородном постоянном поле методом пространственных интегральных уравнений/ Дефектоскопия. 2003. № 8. C. 7I-84. http://naukarus.com/chislennoe-modelirovanie-magnitnogo-sostoyaniya-ferromagnetika-v-neodnorodnom-postoyannom-pole-metodom-prostranstvennyh-i

4. Игнатьев В.К., Орлов А.А. Обратная магнитостатическая задача для ферромагнетиков/ Наука и образование. I января 20I4. С. $300-324$. http://technomagelpub.elpub.ru/jour/article/viewFile/467/469. 
5. Жирков В.Ф., Новиков К.В., Сушкова Л.Т. Решение обратной задачи магнитостатики методом регуляризации Тихонова. http://autex.spb.su/download/dsp/dspa/dspa2005/tl/74.pdf.

6. Дякин В.В., Кудряшова О.В., Раевский В.Я. К вопросу корректности прямой и обратной задач магнитостатики. Часть І. Дефектоскопия. №7, 2017. C. $35-45$.

https://www.libnauka.ru/journal/defektoskopiya/defektoskopiya-20I7-7/voprosu-korrektnosti-pryamoy-i-obratnoy-zadach-magnitostatiki-chast-I-defektoskopiyal

7. Печенков А.Н. Алгоритмы расчетов и моделирования прямых и обратных задач магнитостатической дефектоскопии и устройств технической магнитостатики. доктора технических наук. Автореферат на соиск доктора техн наук. 05.02.II - Методы контроля и диагностика в машиностроении. Екатеринбург. 2007. 42 с.

8. Жидков Е.П., Перепелкин Е.Е. Поведение решения нелинейной задачи магнитостатики в окрестности угловой точки ферромагнетика // Матем. Моделирование. № I5(4). 2003. С. 77-84. http://www.mathnet.ru/links/8987cc5434c5f5d6fd5efd33fe588I2b/mm47I.pdf.

9. Решение одной нелинейной обратной задачи магнитостатики методом регуляризации / Е.П. Жидков, И.В. Куц, Р.В. Полякова и др. Дубна: ОИяИ, 1988. 10 с. (Препр. Объед. ин-т ядер. исслед.; РІІ-88-335). https://search.rsl.ru/ru/record/0I00।422। 97.

10. Shur M.L., Novoslugina A.P., Smorodinskii Ya.G. On the Inverse Problem of Magnetostatics/ Russian Journal of Nondestructive Testing, 2013, Vol. 49, No. 8, pp. 465-473. http://elar.urfu.ru/bitstream/10995/27292/I/scopus-2013-0456.pdf.

II. Шарый С.П. Интервальные методы для регуляризации плохообусловленных и некорректных задач. Институт вычислительных технологий СО РАН Новосибирский государственный университет. XVIII Всероссийская конференция молодых учёных по математическому моделированию и информационным технологиям. http://conf.nsc.ru/files/conferences/ym2017/4I538I/Sharyi_SP-YM20I7.pdf

12. Денисов А.М. Метод решения уравнений І-го рода в гильбертовом пространстве // Докл. АН СССР. 1984. Т. 274, № 3. С. $528-530$.

15. Верлань А.Ф., Сизиков В.С. Интегральные уравнения: методы, алго-ритмы, программы. Киев: Наукова думка, 1986.128 с.

16. Треногин В.А. Функциональный анализ. М.: Наука, 1980. 495 с.

17. Dyakin V.V., Kudryashova O.V., Raevskii V.Y. On the solution of the magnetostatic field problem in the case of magnetic permeability that is dependent on coordinates. // Russian Journal of Nondestructive Testing. 20I5. V. 5I. No 9. P. 554-562.

18. Кротов Л.Н. Моделирование обратной геометрической задачи магнитостатики в магнитном контроле. Автореф. дисс. на соиск. уч. ст. д-ра физ.матем. Наук. Пермь. 2004. http://www.science.by/upload/iblock/915/915879eb2bc1677d493a2262187274b0.pdf.

19. Акишин П.Г., Сапожников А.А. Метод объёмных интегральных уравнений в задачах магнитостатики // Журнал Вестник РУДН. Серия: Математика, информатика, физика. №2. 20।4. С. 3І0-3।5. https://cyberleninka.ru/article/n/metod-obyomnyh-integralnyh-uravneniy-v-zadachah-magnitostatiki.

20. Арутюнян Р.В., Некрасов С.А., Середина П.Б. Идентификация намагниченности постоянных магнитов на основе метода скалярного магнитного потенциала // Изв. вузов. Электромеханика. №6. 2018.

21. Жермен-Лакур П., Жорж П.Л., Пистр Ф., Безье П. Математика и САПР. М.: Мир, 1989. 264 с.

22. Денисов П.А. Описание петли гистерезиса с использованием явных вы-ражений для модели Джилса-Атертона второго уровня // Изв. вузов. Элек-тромеханика. 2018. Т. 61, № І. С. 6-12.

\section{Информация об авторе:}

Арутюнян Роберт Владимирович, Московский государственный технический университет имени Н.Э.Баумана, Москва, Россия, к.ф.-м.н., доцент кафедры "Вычислительная математика и математическая физика", Москва, Россия 